\title{
Activity of the 5-HT1A receptor is involved in the alteration of glucocorticoid receptor in hippocampus and corticotropin- releasing factor in hypothalamus in SPS rats
}

\author{
HAI-TAO WANG, FANG HAN and YU-XIU SHI
}

\begin{abstract}
Department of Histology and Embryology, Basic Medical Sciences College, China Medical University, Shenyang 110001, Liaoning Province, P.R. China
\end{abstract}

Received April 1, 2009; Accepted May 22, 2009

DOI: 10.3892/ijmm_00000225

\begin{abstract}
Rats exposed to single-prolonged stress (SPS) showed enhanced inhibition of the hypothalamic-pituitaryadrenal (HPA) system and alteration in the glucocorticoid/ mineralocorticoid receptor. Dysfuntion of the HPA axis is one of the core neuroendocrine abnormalities of post-traumatic stress disorder (PTSD). Serotonergic receptor, glucocorticoid receptor (GR) and corticotropin-releasing factor (CRF) have been proposed to play major roles in dysfuntion of the HPA axis. However, the precise molecular mechanism is unknown. In this study, we investigated the relationships between the changes of GR in hippocampus as well as CRF in hypothalamus and the activity of 5-HT1A receptor in SPS rats. We exposed rats to SPS with or without prior treatment with WAY 100635 (the 5-HT1A receptor antagonist), and observed behavioral changes, GR levels in the hippocampus and CRF levels in the hypothalamus by immunohistochemistry, Western blotting and RT-PCR seven days after SPS. Our results demonstrate that SPS increases expression of GR and CRF, which were partially inhibited by WAY100635 .
\end{abstract}

\section{Introduction}

Post-traumatic stress disorder (PTSD), an anxiety disorder, develops after a life-threatening, traumatic experience, and is characterized by symptoms that often endure for years including intrusive memories (flashbacks), avoidance of stimuli associated with the trauma, numbing of general responsiveness, and increased arousal (1). Negative feedback of the enhanced hypothalamic-pituitary-adrenal (HPA) axis is a putative neuroendocrinological hallmark of PTSD (2-4). It was reported that single-prolonged stress (SPS), a putative PTSD animal model,

Correspondence to: Professor Yuxiu Shi, Department of Histology and Embryology, Basic Medical Sciences College, China Medical University, 92 North 2nd Road, Shenyang 110001, Liaoning Province, P.R. China

E-mail: shiyuxiu@163.com

Key words: serotonin type 1A receptor, single-prolonged stress, glucocorticoid receptor, corticotropin-releasing factor, post-traumatic stress disorder presents behavioral alterations resembling and showing the most consistent neuroendocrinologic characteristics with PTSD patients (5-8).

As a kind of neurotransmitter, serotonin (5-hydroxytryptamine, 5-HT) plays an important role in controlling the complex neuronal communication, such as negative feedback of the HPA axis via the serotonergic receptor $(9,10)$. It was proposed that serotonergic type $1 \mathrm{~A}(5-\mathrm{HT} 1 \mathrm{~A})$ receptor has an important effect on mood and anxiety modulation $(11,12)$, but keeps the role of serotonin receptor on PTSD contradicative $(13,14)$. Several brain regions, such as the hippocampus and hypothalamus, which have abundant glucocorticoid receptors (GR), are involved in the regulation of stress $(15,16)$. Rats exposed to SPS show an enhanced negative feedback through upregulation of GR mRNA and downregulation of mineralocorticoid receptor mRNA in the hippocampus 7 days after SPS (5). The corticotropin-releasing factor (CRF) in the para ventricular nucleus (PVN) affects the releasing of the adrenocorticotropic hormone (ACTH) from the anterior pituitary during stress (17). Induction of CRF in the PVN is a frequently observed stress related response reflecting activation of the HPA axis (18). However, the precise molecular mechanism of dysfunction of the HPA axis remains unclear.

In the present study, we hypothesized that the activity of 5-HT1A receptor is involved in the changes of GR and CRF in SPS rats. To investigate the effect of 5-HT1A receptor on GR and CRF, we exposed rats to SPS with or without prior treatment with WAY100635 (the 5-HT1A receptor antagonist) and observed the behavioral changes, GR levels in the hippocampus and CRF levels in the hypothalamus by immunohistochemistry, Western blotting and RT-PCR.

\section{Materials and methods}

Experimental animals. Male Sprague-Dawley (SD) rats, 7 or 8 weeks old and weighing 240-280 g, were purchased from China Medical University. Rats were housed in an airconditioned room $\left(22 \pm 1^{\circ} \mathrm{C}\right.$ and $55 \pm 5 \%$ humidity) with a 12 -h light/dark cycle and given standard chow and tap water. All procedures followed the National Guidelines on Animal Care.

Inducution of the SPS model. SD rats were randomly divived into 4 groups ( $n=20$ per group): i) normal group, ii) sham group (vehicle administration), iii) SPS group (SPS + vehicle 
Table I. The sequence of GR, CRF and $\beta$-actin.

\begin{tabular}{|c|c|c|c|}
\hline Name & Upstream primer & Downstream primer & $\begin{array}{c}\text { Product size } \\
\text { (bp) }\end{array}$ \\
\hline GR & $\begin{array}{l}\text { 5'-atcccacagac } \\
\text { caaagcacctt-3' }\end{array}$ & $\begin{array}{l}\text { 5'-tccagttttcag } \\
\text { aaccaacagg-3' }\end{array}$ & 540 \\
\hline $\mathrm{CRF}$ & $\begin{array}{l}5^{\prime}-\text { ccgcagccg } \\
\text { ttgaatttcttg-3' }\end{array}$ & $\begin{array}{l}\text { 5'-agatatcgcta } \\
\text { taaagacact-3' }\end{array}$ & 720 \\
\hline B-actin & $\begin{array}{c}5^{\prime} \text {-atcacccacac } \\
\text { tgtgcccatc-3' }\end{array}$ & $\begin{array}{l}\text { 5'-acagagtact } \\
\text { tgcgctcagga-3' }\end{array}$ & 542 \\
\hline
\end{tabular}

administration), and iv) blockade group (SPS + WAY100635 administration). The SPS model was created as described previously (19). Briefly, rats were restrained for $2 \mathrm{~h}$ and immediately forced to swim for $20 \mathrm{~min}$ in water $\left(24^{\circ} \mathrm{C}\right)$. After a 15 -min rest, they were anaesthetized by ether and then laid in their cages without disturbance. The rats in the blockade group were treated with WAY100635 (Sigma, USA, dissolved in normal saline, $3.0 \mathrm{mg} / \mathrm{kg}$ s.c.) $30 \mathrm{~min}$ before SPS (20) while normal saline to replace WAY100635 in SPS group (Sigma, dissolved in normal saline, $3.0 \mathrm{mg} / \mathrm{kg}$, s.c.). Rats with the sham group were treated with normal saline only.

Morris water maze test. To test hippocampal-dependent spatial cognition, the rats (5 rats from each group) were trained in the standard Morris water maze (MWM) with a hidden platform. A 5-day testing study was performed as previously described in detail (21). Briefly, rats were gently placed in the water between quadrants, facing the wall of the pool, to find a submerged platform within $120 \mathrm{sec}$. Then, they were allowed to stay on the platform for $20 \mathrm{sec}$. If failing, they were guided gently to find the platform and stay there for $20 \mathrm{sec}$. For each rat, there were 4 measurement times with different dropping location. The whole process was recorded by video and the escape latency (EL) time was analyzed by image tracking software (China Daheng Group, Inc., Beijing Image Vision Technology Branch, Beijing, China).

Brain tissue preparation. From each group, 5 rats were transcardially infused with $200-300 \mathrm{ml}$ of pre-cold saline through the ascending aorta, followed by $300 \mathrm{ml}$ of $4 \%$ pre-cold paraformaldehyde. The whole brain was rapidly removed and dissected on ice, followed by $6-10 \mathrm{~h}$ of post-fixation in $4 \%$ paraformaldehyde at $4^{\circ} \mathrm{C}$. After immersed in $20 \%$ sucrose solution and frozen in liquid nitrogen, the brain tissue was cut into slices with $15 \mu \mathrm{m}$ in thickness and stored in $-70^{\circ} \mathrm{C}$. For other rats (10 rats from each group), the hippocampus and hypothalamus were quickly dissected from the brain and stored at $-80^{\circ} \mathrm{C}$.

Immunohistochemical analysis of GR and CRF. After treated with $1 \%$ hydrogen peroxide/methanol, sections were incubated with $10 \%$ normal rabbit serum for $30 \mathrm{~min}$ at $37^{\circ} \mathrm{C}$, the I antibody (anti-GR, Santa Cruz, USA; anti-CRF, Boster Biological Technology Ltd., China; both 1:200 dilution) for overnight at $4^{\circ} \mathrm{C}$, and the II antibody (Boster Biological Technology Ltd., 1:200 dilution) for $1 \mathrm{~h}$ at $37^{\circ} \mathrm{C}$. Then, the sections were incubated with avidin-biotin peroxidase

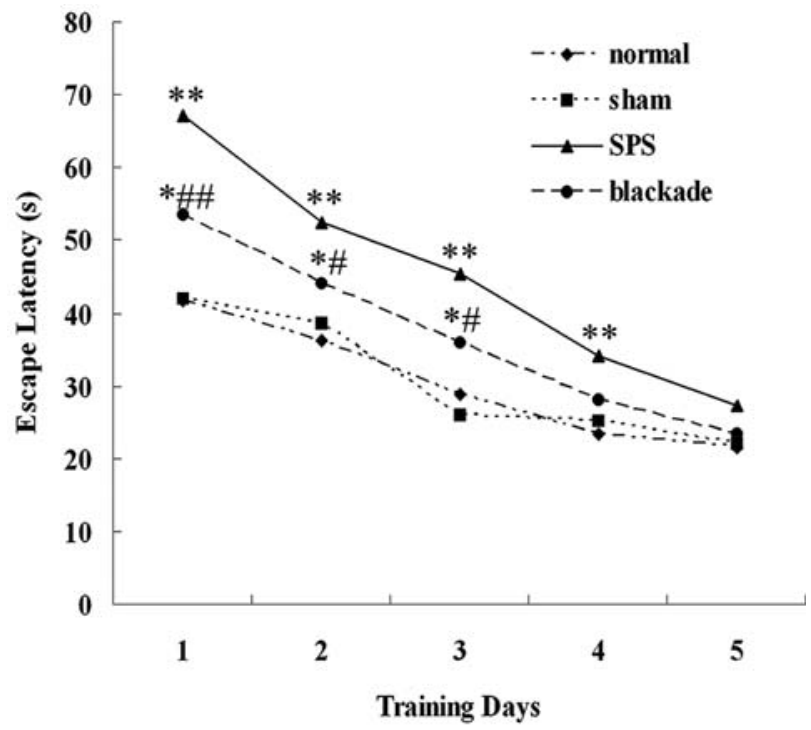

Figure 1. Performance of rats during five training days of finding a hidden platform. ${ }^{*} \mathrm{P}<0.05,{ }^{* *} \mathrm{P}<0.01$, compared with normal and sham; ${ }^{*} \mathrm{P}<0.05$,

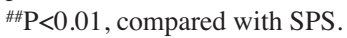

complex (Boster Biological Technology Ltd., 1:200 dilution) for $1 \mathrm{~h}$ at $37^{\circ} \mathrm{C}$ and immunocomplexes were finally visualized with $0.05 \%$ DAB. An independent investigator obtained images from five slices of each rat and results were analyzed by an image analyzer. CA1 and dentate gyrus subregions were used to analyze GR expression, while hypothalamus was used to analyze CRF.

Western blotting to detect GR. The tissue of the hippocampus was homogenized in lysis buffer (50 mM Tris buffer, $250 \mathrm{mM}$ $\mathrm{NaCl}, 0.1 \% \mathrm{NP}-40,1 \mathrm{mM} \mathrm{NaF}, 0.1 \mathrm{mM} \mathrm{Na} \mathrm{VO}_{4}, 0.5 \mathrm{mM}$ EDTA, $0.5 \mathrm{mM}$ EGTA, $10 \mu \mathrm{g} / \mathrm{ml}$ leupeptin, $10 \mu \mathrm{g} / \mathrm{ml}$ aprotinin, $100 \mu \mathrm{g} / \mathrm{ml}$ PMSF) and centrifuged at 15,000 $\mathrm{g}$ at $4^{\circ} \mathrm{C}$ for $30 \mathrm{~min}$. The supernatants were collected and protein content detected with BCA protein assay kit. Protein $(30 \mu \mathrm{g})$ was separated in $10 \%$ SDS-PAGE and transferred onto PVDF membranes (Millipore, Bedford, MA, USA). After blocked with 5\% skimmed milk, the membrane was incubated with I antibody (anti-GR, Santa Cruz, 1:500; anti-ß-actin, Abcam, $1: 1,000$ ) for $24 \mathrm{~h}$ at $4^{\circ} \mathrm{C}$ and II antibody (Boster Biological Technology Ltd., 1:3,000) for $2 \mathrm{~h}$ at room temperature. Blots were subjected to autoradiography (ECL reagents, Amersham Pharmacia Biotech, Buckinghamshire, UK). The optical density (OD) of GR and B-actin were analyzed by Gel Image Analysis System (Tanon 2500R, Shanghai, China). The levels of GR were normalized by $\beta$-actin.

Reverse transcription-polymerase chain reaction ( $R T-P C R)$ to detect GR and GRF. Total RNA was isolated from the hippocampi and hypothalamuses by Trizol (Invitrogen, USA) and $1 \mu \mathrm{g}$ of total RNA was reverse transcribed into cDNA. cDNA was amplified using a RNA PCR kit (AM Ver. 3.0, Takara Bio, Otsu, Japan). The specific primers were synthetized from Sangon Biological Engineering Technology $\&$ Services Co. Ltd. (Shanghai, China). The sequence of each gene is shown in Table I. The amplification profile includes: i) denaturation at $94^{\circ} \mathrm{C}$ for $5 \mathrm{~min}$, ii) 32 additional cycles at 

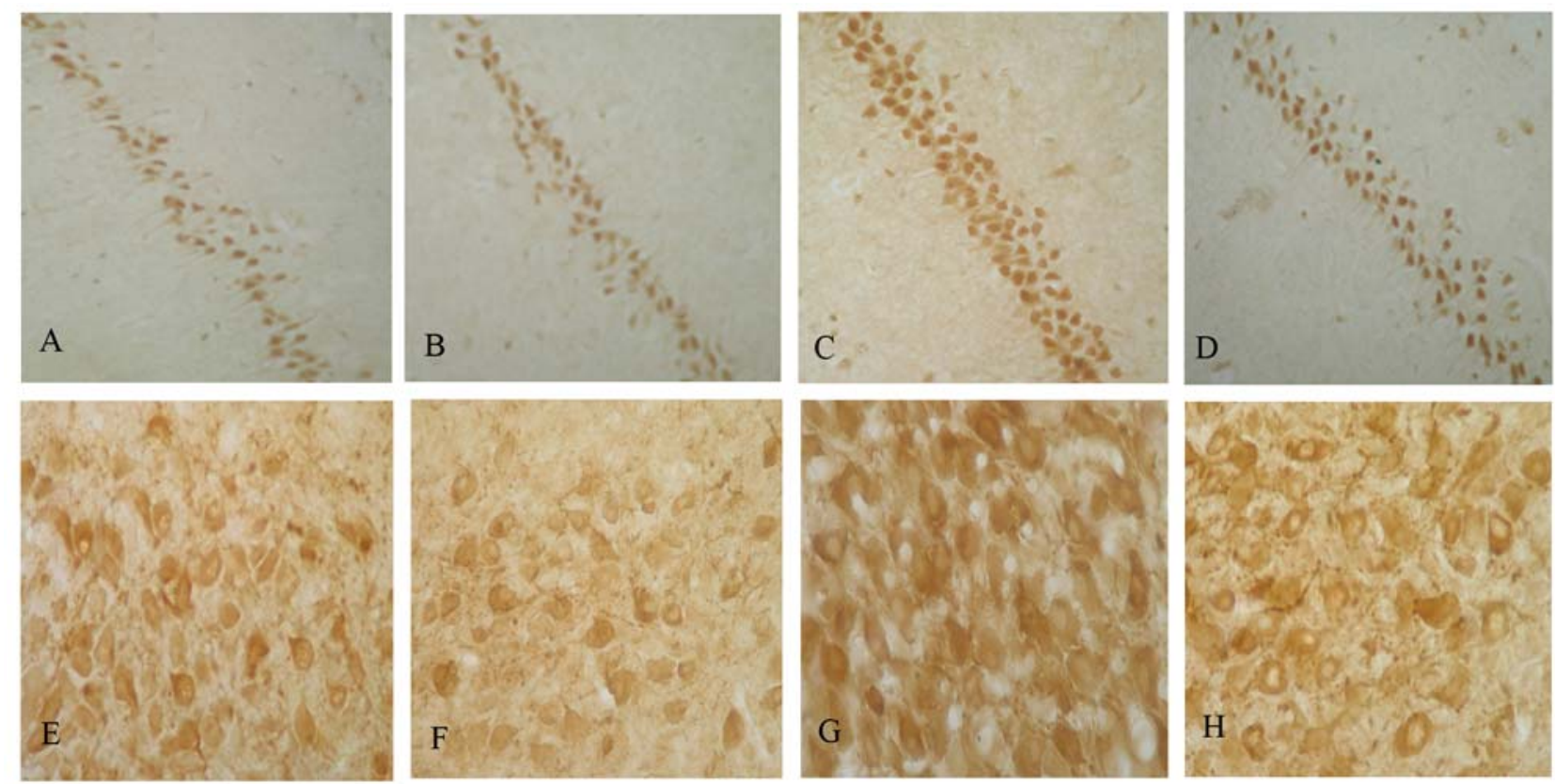

Figure 2. Presentation of GR expression in the CA1 of hippocampus (A-D, magnification x100) and CRF in hypothalamus (E-H, magnification x400). The GR-immunoreactive cell quantity of SPS rats (C) exceeds that of normal (A) and sham (B) rats, whereas fewer GR-immunoreactive cells were distributed in blockade rats (D). CRF-immunoreactive cell quantity of SPS rats (G) also exceeds that of normal (E) and sham (F) rats, and fewer CRF-immunoreactive cells were distributed in blockade rats $(\mathrm{H})$.

$94^{\circ} \mathrm{C}$ for 50 and then $45 \mathrm{sec}$ at $56.5^{\circ} \mathrm{C}$ (for GR) and $58^{\circ} \mathrm{C}$ for (for $\mathrm{CRF}$ ), $72^{\circ} \mathrm{C}$ for $50 \mathrm{sec}$, and iii) extension at $72^{\circ} \mathrm{C}$ for $8 \mathrm{~min}$. The PCR products were separated on $1.5 \%$ agarose gel by electrophoresis and the density of each band was analyzed on the Gel Image Analysis System (Tanon 2500R, Shanghai China). The levels of GR and CRF mRNA were normalized by $ß$-actin.

Statistical analysis. All values are presented as the means \pm standard error of means (SEM) and analyzed using SPSS 13.0. Statistical significance was deterrmined by one-way analysis of variance (ANOVA), followed by the Tukey test when appropriate. $\mathrm{P}<0.05$ was considered as statistically significant.

\section{Results}

Hidden platform trial. Fig. 1 shows the learning curves in the Morris water maze test to show EL time during 5-day training. There is no difference in EL between normal and sham groups. Compared with normal and sham groups, SPS significantly increased its EL during the first four days, $(\mathrm{P}<0.01)$, which were partially blocked by WAY100635 during the first three days. Althoug EL in the blocked group is still higher than the normal and sham groups, their abilities to reach the hidden platform shows a marked increase during the first three days. At the fifth day, there is no difference among the groups.

Results of immunohistochemical analysis of GR and CRF. There was no statistically significant difference between normal and sham groups. Compared to the normal and sham groups, expression of GR and CRF increased in SPS, which were partially blocked by WAY100635 (Table II, Fig. 2).
Table II. A quantitative analysis of GR expression in the hippocampus and CRF expression in the hypothalamus.

\begin{tabular}{lcc}
\hline \multirow{2}{*}{ Group } & \multicolumn{2}{c}{ Immunoreactive cell density $\left(\right.$ number $\left./ \mathrm{mm}^{2}\right)$} \\
\cline { 2 - 3 } & \multicolumn{1}{c}{ GR } & CRF \\
\hline Normal & $182.00 \pm 12.53$ & $69.40 \pm 6.07$ \\
Sham & $174.00 \pm 10.34$ & $67.00 \pm 10.10$ \\
SPS & $387.80 \pm 16.16^{\mathrm{b}}$ & $223.60 \pm 15.48^{\mathrm{b}}$ \\
Blockade & $309.80 \pm 27.18^{\mathrm{b}, \mathrm{c}}$ & $168.60 \pm 16.50^{\mathrm{b}, \mathrm{c}}$ \\
\hline
\end{tabular}

${ }^{a} \mathrm{P}<0.05$ vs normal and sham; ${ }^{\mathrm{b}}<0.01$ vs normal and sham; ${ }^{\mathrm{C}} \mathrm{P}<0.05$ vs $\mathrm{SPS}$.

GR expression detected by Western blotting. Similar to the immunohistological staining, there was GR expression in the hippocampus area when rats were under normal conditions. SPS significantly increased the GR expression which is partially decreased by WAY100635. The results indicate that SPS stimulates the expression of GR, but this increase is inhibited by 5-HT1A receptor antagonist (Fig. 3).

GR and CRF mRNA expression. The levels of GR mRNA in hippocampus and CRF mRNA in hypothalamus were detected by RT-PCR. There was both GR and CRF expression in the normal condition. Compared with the normal group, sham had no effect on the GR and CRF mRNA expression, however, SPS significantly increased their expression which were partially decreased by WAY100635. The results indicate that SPS stimulates the expression of GR, but this increase is inhibited by 5-HT1A receptor antagonist (Fig. 4). 


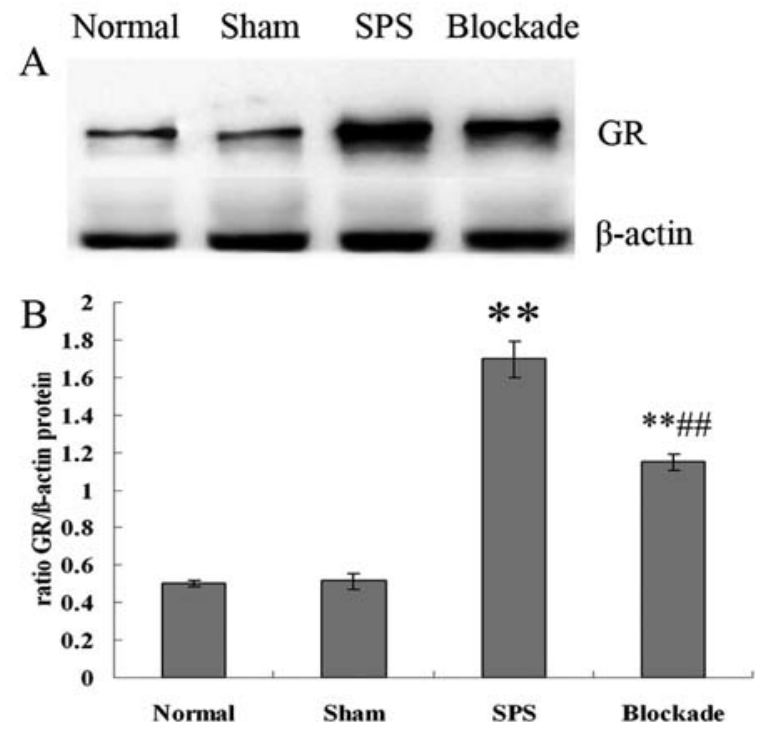

Figure 3. GR expression in the CA1 of hippocampus detected by Western blotting. Presentation of bands show GR protein levels (A). Relative quantitative data levels of GR (B). ${ }^{*} \mathrm{P}<0.05$ vs normal and sham; ${ }^{* *} \mathrm{P}<0.01$ vs normal and sham; ${ }^{\# \#} \mathrm{P}<0.01$ vs SPS.

\section{Discussion}

The pathogenesis of PTSD should be elucidated. SPS is a good animal model of PTSD based on the time-dependent dysregulation of the HPA axis, since it shares the most consistent neuroendocrinologic characteristics with PTSD patients (19). Rats subjected to SPS show enhanced negative feedback through upregulation of GR mRNA and downregulation of mineralocorticoid receptor (MR) mRNA in the hippocampus 7 days after SPS (5). Furthermore, SPS rats have an exaggerated acoustic startle response (22) and enhanced contextual freezing $(6,23)$. These findings suggest that SPS causes enhanced sensitivity to stimuli, which resembles the trauma-related and unrelated psychophysiological responses in patients with PTSD. However, the precise mechanisms by which the HPA axis are dysregulated and PTSD develops remains unknown. The aim of this study was to determine whether blocking 5-HT1A receptor influences GR and CRF expression in SPS.

Rats were assessed for their spatial memory performance using the Morris water maze task. SPS impairs the acquisition of spatial memory (7). In our study, there was a significant difference in the performance of EL between SPS and normal rats. Moreover, blockade group rats improved their performance in finding the hidden platform. These observations suggest that SPS rats exhibit obvious deterioration in learning ability and memory tasks, associated with the activity of 5-HT1A receptor.

Since behavioral changes were observed 7 days after SPS (7), changes in hippocampal GR expression and hypothalamic CRF expression were detected simultaneously. Our study demonstrates that SPS increased the levels of GR mRNA and protein in the hippocampus and CRF mRNA and protein in the hypothalamus. These results are consistent with some previous reports $(5,19,24,25)$. Furthermore, we also found that the mRNA and protein of GR and CRF decreased after blockading 5-HT1A receptor compared to SPS rats.
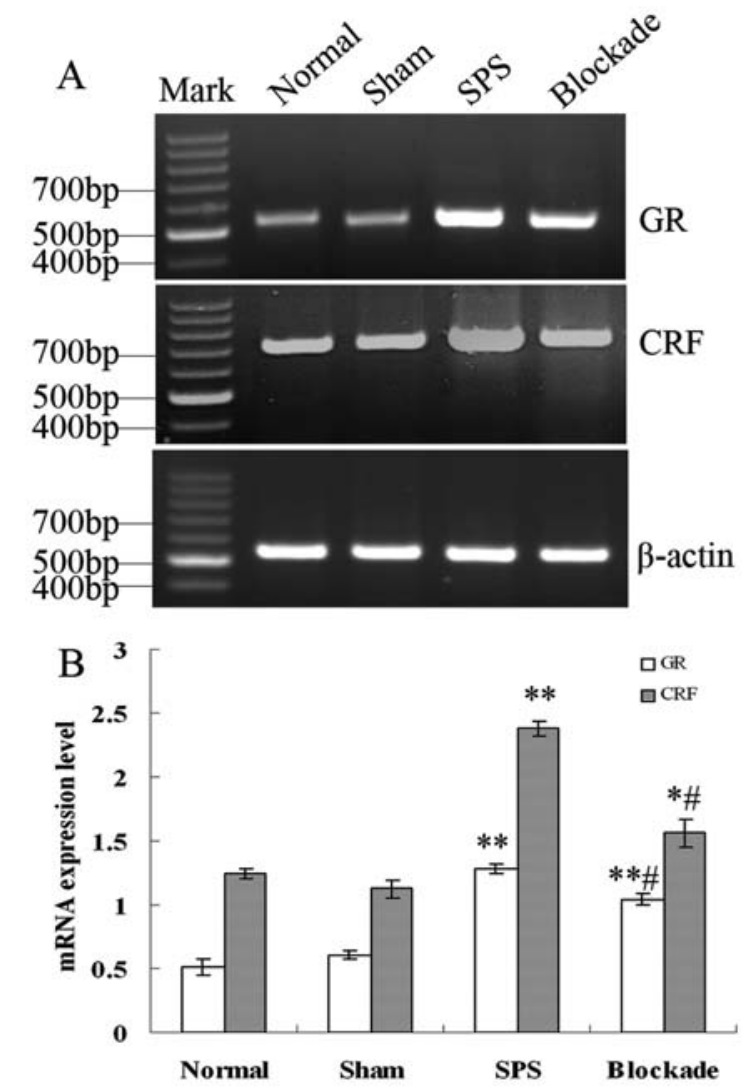

Figure 4. The representative gel patterm of GR, CRF, B-actin of cDNA bands (A) and relative amounts of GR and CRF mRNA (B). Lane 0, marker; lane 1, normal; lane 2, sham; lane 3, SPS; lane 4, blockade. ${ }^{*} \mathrm{P}<0.05$ vs normal and sham; ${ }^{* *} \mathrm{P}<0.01$ vs normal and sham; ${ }^{*} \mathrm{P}<0.05$ vs SPS.

Under stress situations, hippocampal GR is sensitive to elevated glucocorticoid levels (26). After 7 days of SPS, the GR mRNA expression in the hippocampus increased (5). GR activation might play a critical role in producing the altered behavior and neuronal function of SPS rats (7). It is well documented that the overactivity of the HPA axis in depression is due to an abnormality of the GR at the limbic-hippocampal level (27). Our results are consistent with this finding. However, our group recently observed the opposite effect of SPS on GR level in the hippocampus (28). We think that there are two possibilities: i) different animal species used in experiments cause different expression of receptor; ii) density of the activated receptors detected by antibodies was different. Cortisol in plasma, awakening saliva or 24-h urinary in animal models subjected to war-related PTSD were lower than in healthy individuals with or without exposure to trauma (29). Subjects with PTSD have also exhibited greater suppression of the adrenocorticotropin hormone (ACTH) and cortisol in plasma and lymphocyte GR in response to dexamethasone $(30,31)$. Cerebrospinal fluid (CSF) concentrations of CRF were higher in PTSD patients $(24,25)$. We also observed that CRF proteins and mRNA were increased 7 days after SPS.

In the present study, we examined SPS induced upregulation of GR and CRF expression, and found that GR and CRF decreased after blockade of the activity of 5-HT1A receptor. This result could help understand the dysregulation of the HPA axis in PTSD. In SPS, stress may upregulate GR and CRF via activation of 5-HT1A receptor. Blockade of 
5-HT1A receptor downregulates GR and CRF, which is a new way to synthetize new drugs and retrieve the dysfunction of HPA axis in SPS. After SPS, stress might affect the protein and mRNA expression of GR and CRF through the 5-HT1A receptor, and induces dyfunction of the HPA axis.

In this study, we only focus on the changes of GR and CRF in SPS rats with and without 5-HT1A receptor antagonist. There are still some limitations, for example, we did not examine on the changes of 5-HT and the relationship between GR and CRF as well as 5-HT. We did not detect whether there are similar changes in other regions. However, this study clearly shows that activity of 5-HT1A receptor is involved in the alteration of GR and CRF in SPS rats.

\section{Acknowledgements}

This research is supported by a grant from the National Natural Science Foundation of China (No. 30600341). The authors are thankful for all the help from the China Medical University Experiment Center for their technical support.

\section{References}

1. American Psychiatric Association: Diagnostic and Statistical Manual of Mental Disorders, 4th ed. DSM-IV. American Psychiatric Press, Washington DC, 1994.

2. Yehuda R: Biology of post-traumatic stress disorder. J Clin Psychiatry 62: 41-46, 2001.

3. Yehuda R, Southwick SM, Krystal JH, Bremner D, Charney DS and Mason JW: Enhanced suppression of cortisol following dexamethasone administration in post-traumatic stress disorder. Am J Psychiatry 150: 83-86, 1993.

4. Yehuada R: Neuroendocrine aspects of PTSD. Handb Exp Pharmacol: 371-403, 2005.

5. Liberzon I, López JF, Flagel SB, Vázquez DM and Young EA: Differential regulation of hippocampal glucocorticoid receptors mRNA and fast feedback: relevance to post-traumatic stress disorder. J Neuroendocrinol 11: 11-17, 1999.

6. Takahashi T, Morinobu S, Iwamoto Y and Yamawaki S: Effect of paroxetine on enhanced contextual fear induced by single prolonged stress in rats. Psychopharmacology 189: 165-173, 2006.

7. Kohda K, Harada K, Kato K, Hoshino A, Motohashi J, Yamaji T, Morinobu S, Matsuoka N and Kato N: Glucocorticoid receptor activation is involved in producing abnormal phenotypes of single-prolonged stress rats: a putative post-traumatic stress disorder model. Neuroscience 148: 22-33, 2007.

8. Yamamoto S, Morinobu S, Fuchikami M, Kurata A, Kozuru T and Yamawaki S: Effects of single prolonged stress and D-cycloserine on contextual fear extinction and hippocampal NMDA receptor expression in a rat model of PTSD. Neuropsychopharmacology 33: 2108-2116, 2008

9. Lucki I: The spectrum of behaviors influenced by serotonin. Biol Psychiatry 44: 151-162, 1998.

10. McAllister-Williams RH, Ferrier IN and Young AH: Mood and neuropsychological function in depression: the role of corticosteroids and serotonin. Psychol Med 28: 573-584, 1998.

11. Millan MJ: The neurobiology and control of anxious states. Prog Neurobiol 70: 83-244, 2003.

12. Gross C, Zhuang X, Stark K, Ramboz S, Oosting R, Kirby L, Santarelli L, Beck S and Hen R: Serotonin 1 A receptor acts during development to establish normal anxiety-like behaviour in the adult. Nature 416: 396-400, 2002.
13. Tanaka-Gomi N, Yasuda K, Nakamura M, Hasumi-Nakayama Y, Umemura T, Tanaka S and Furusawa K: Postnatal changes in $5 \mathrm{HT}$ and $\mathrm{NK} 1$ receptors in rat trigeminal motor nucleus and surroundings. Int J Dev Neurosci 25: 427-432, 2007.

14. Bonne O, Bain E, Neumeister A, Nugent AC, Vythilingam M, Carson RE, Luckenbaugh DA, Eckelman W, Herscovitch P, Drevets WC and Charney DS: No change in serotonin type 1A receptor binding in patients with post-traumatic stress disorder. Am J Psychiatry 162: 383-385, 2005.

15. Feldman S and Weidenfeld J: Glucocorticoid receptor antagonists in the hippocampus modify the negative feedback following neural stimuli. Brain Res 821: 33-37, 1999.

16. Kitraki E, Karandrea D and Kittas C: Long-lasting effects of stress on glucocorticoid receptor gene expression in the rat brain. Neuroendocrinology 69: 331-338, 1999.

17. Vale W, Spiess J, Rivier C and Rivier J: Characterization of a 41-residue ovine hypothalamic peptide that stimulates secretion of corticotropin and beta-endorphin. Science 213: 1394-1397, 1981.

18. Watts AG: The impact of physiological stimuli on the expression of corticotropin-releasing hormone (CRH) and other neuropeptide genes. Front Neuroendocrinol 17: 281-326, 1996.

19. Liberzon I, Krstov M and Young EA: Stress-restress: effects on ACTH and fast feedback. Psychoneuroendocrinology 22: 443-453, 1997.

20. Shannon HE and Lutz EA: Yohimbine produces antinociception in the formalin test in rats: involvement of serotonin(1A) receptors. Psychopharmacology 149: 93-97, 2000.

21. Yu J, Liu C, Zhang X and Han J: Acupuncture improved cognitive impairment caused by multi-infarct dementia in rats. Physiol Behav 86: 434-441, 2005.

22. Khan S and Liberzon I: Topiramate attenuates exaggerated acoustic startle in an animal model of PTSD. Psychopharmacology 172: 225-229, 2004

23. Imanaka $A$, Morinobu $S$, Toki $S$ and Yamawaki S: Importance of early environment in the development of post-traumatic stress disorder-like behaviors. Behav Brain Res 173: 129-137, 2006.

24. Bremner J, Licinio J, Darnell A, Krysal JH, Owens MJ, Southwick SM, Nemeroff CB and Charney DS: Elevated CSF corticotropin releasing factor concentrations in post-traumatic stress disorder. Am J Psychiatry 154: 624-629, 1997.

25. Baker DG, West SA, Nicholson WE, Ekhator NN, Kasckow JW Hill KK, Bruce AB, Orth DN and Geracioti TD Jr: Serial CSF corticotropin-releasing hormone levels and adrenocortical activity in combat veterans with post-traumatic stress disorder. Am J Psychiatry 156: 585-588, 1999.

26. Reul JM and de Kloet ER: Two receptor systems for corticosterone in rat brain: microdistribution and defferential occupation. Endocrinology 117: 2505-2511, 1985.

27. Pariante CM and Miller AH: Glucocorticoid receptors in major depression: relevance to pathophysiology and treatment. Biol Psychiatry 49: 391-404, 2001.

28. Du Z, Han F and Shi Y: Expressions of hippocapal mineralocorticoid receptor (MR) and glucocorticoid receptor (GR) in the single-prolonged stress rats. Acta Histochem Cytochem 41: 89-95, 2008.

29. Rohleder N, Joksimovic L, Wolf JM and Kirschbaum C: Hypocortisolism and increased glucocorticoid sensitivity of proinflammatory cytokine production in Bosnian war refugees with post-traumatic stress disorder. Biol Psychiatry 55: 745-751, 2004.

30. Yehuda R, Golier JA, Meany M and Bierer LM: The ACTH response to dexamethasone in PTSD. Am J Psychiatry 161: 1397-1403, 2004.

31. Yehuda R, Halligan SL, Golier JA, Grossman R and Bierer LM: Effects of trauma exposure on the cortisol response to dexamethasone administration in PTSD and major depressive disorder. Psychoneuroendocrinology 29: 389-404, 2004. 